\title{
Analysis of the Bolivian Universities Scientific Production
}

\author{
Natalia Indira Vargas-Cuentas ${ }^{*}, 1$, Avid Roman-Gonzalez ${ }^{2}$ \\ ${ }^{1}$ Image Processing Research Laboratory (INTI-Lab), Universidad de Ciencias y Humanidades (UCH), Lima, 15314, Peru \\ ${ }^{2}$ Business on Engineering and Technology S.A.C. (BE Tech), Lima, 15076, Peru
}

\begin{tabular}{l} 
A R T I C L E I N F O \\
\hline Article history: \\
Received: 16 October, 2020 \\
Accepted: 24 January, 2021 \\
Online: 25 February, 2021 \\
\hline Keywords: \\
SDGs \\
Scientific production assessment \\
SCOPUS \\
SIR World \\
SIR Iber \\
Vanguardia
\end{tabular}

\section{Introduction}

The United Nations (UN) indicates that one of the 17 sustainable development goals is to provide quality education [1]; it is essential to speak of higher education for sustainable development in this context. That is why universities are encouraged to fulfill the mission of becoming centers of learning and research for sustainable development within their communities [2].

However, according to [3, 4], Bolivia's universities, together with other countries of the Andean region such as Ecuador and Peru, have not been structured in their beginning from substantial scientific communities. For this reason, the higher education systems of the three countries did not develop enough scientific bases, so they suffer from academic weakness at the institutional level [5].

Bolivia is a country located in South America; it is an Andean country with 11,353,100 inhabitants, according to data from the World Bank [6]. The GDP assigned to the research and development (R\&D) sector in Bolivia is $0.16 \%$, according to

\footnotetext{
* Corresponding Author: Natalia I. Vargas-Cuentas, Av. Universitaria 5175, Los Olivos, natalia.i.vargascuentas@ieee.org www.astesj.com
}

https://dx.doi.org/10.25046/aj0601139
UNESCO (United Nations Educational, Scientific and Cultural Organization) [7]. The country's higher education system comprises 59 universities registered in the Vice Ministry of Higher Education for Professional Training [8]. Bolivian universities are classified into autonomous public universities (11), private universities attached to the Executive Committee of the Bolivian University - CEUB (3), private universities (39), indigenous universities (3), and exceptional regime universities (3).

According to [9], one of the challenges of the Bolivian higher education system is that there is a difference between Bolivian public universities since they try to focus on three functions of higher education: training, research, and interaction, and contrarily private universities tend to focus on their teaching activities without focusing on doing research. The main reason $[2,10]$ is that most university teachers, especially in private universities, do not work full-time, which prevents them from getting involved in scientific research development. It is also mentioned in [5] that university teachers are overloaded with teaching hours and administrative work.

Given this limitation, according to [5] until 2006, many universities have promoted research infrastructure creation. 
According to records, 17 research centers belong to private universities, 25 research institutes belong to government organizations, and 141 belong to the public university system, giving 183 research and development centers located mainly in three departments La Paz, Cochabamba, and Santa Cruz.

Besides, according to [11], there have been national policies to increase human resources in research, for example, the increase in postgraduate programs, both masters and doctoral programs in Bolivia, which left a total of 1,015 research professors and 631 research assistants, in addition to 4,014 completed investigations until 2014. However, these statistics do not include data from private universities. According to UNESCO, for the year 2020, the country has 2,218 full-time equivalent researchers [7].

Another important aspect is the number of Bolivian academicscientific journals indexed in SciELO, RedALyC, and SCOPUS databases. According to [12], until 2011, Bolivia had six journals indexed in SciELO and one journal indexed in SCOPUS; these shows a scarce presence and not in all sources. However, these seven scientific journals included in prestigious databases for the scientific community at the regional and international levels increase Bolivian scientific production's visibility.

In this sense, scientific research and production are essential not only because they allow innovation, the resolution of social demands, and the country's technological development. Also, because there are metrics to classify universities, in which scientific production is an essential factor. This situation is the case of the Scimago Institutions Rankings (SIR) that develops two annual reports. One is SIR World, an institutional ranking of organizations from different sectors that produce research in the world. The other is SIR Iber, which shows the scientific activity of higher education institutions in Ibero-America $[13,14]$. For an institution to enter SIR World, it needs a scientific production of at least 100 research articles indexed in the SCOPUS database per year. Also, to enter SIR Iber, the institution must have at least one document published and indexed in SCOPUS. Additionally, the Academic Ranking of World Universities (ARWU) uses different indicators, including the number of former students and staff who won Nobel prizes, scientific production, and the citation index [15].

The present research seeks to analyze the scientific production developed by Bolivian universities and indexed in SCOPUS from 2010 to mid-2020 and compare it with other countries' scientific production in the South American region. Moreover, the SIR World and SIR Iber report for 2020 will be analyzed to identify the Bolivian universities included in these rankings. Finally, the scientific production indexed in SCOPUS in 2019 and part of 2020 of the five Bolivian universities with the highest scientific production in Bolivia according to SIR Iber 2020 will be presented.

\section{Methodology}

\subsection{Data sources}

The data necessary for the development of this research work are the following:

- Scientific production: The data on scientific production in Bolivia and the rest of South American countries were extracted from SCOPUS, which is an international database that indexes scientific publications, covers scientific journals and books from various publishers $[12,16]$. SCOPUS belongs to Elsevier, a modern global information analysis publisher specializing in science and health [17].

Scientific production data were extracted from 2010 to the end of July 2020. Moreover, due to the constant updating of the database, it was decided to collect scientific production data on the same date, 07/27/2020, for all countries and institutions analyzed in this study.

- Population data: The number of inhabitants of the South American countries was extracted from the open-access data catalog prepared by the World Bank data team [6]; this catalog contains world population data. In all the South American countries analyzed in this study, the population data are updated until 2018.

- Bolivian universities: The list of Bolivian universities was extracted from the guide of universities of the Plurinational State of Bolivia [8], prepared by the Vice-Ministry of Higher Education for Professional Training; this Vice-Ministry is part of the Ministry of Education of Bolivia. This guide is the latest version published and is updated to the year 2016.

- Classification of Bolivian universities by scientific production, this list was extracted from Scimago Institutions Rankings (SIR) from both the SIR World report and the SIR Iber report; both reports correspond to the year 2020 and can be consulted at https://www.scimagoir.com/rankings.php. It should be mentioned that, although both rankings correspond to 2020 , they are prepared based on data from five years from 2014 to 2018 [13].

\subsection{Data preparation and analysis}

In South America, there are 13 countries, all of which are culturally diverse, and their higher education systems have gone through different historical processes, so they present different scientific production levels. These factors added to the fact that all the regional countries have different sizes and amounts of inhabitants.

Therefore, to develop a fair comparison, this study proposes comparing South American countries' scientific production per million inhabitants.

$$
P_{i}=\frac{P_{S}}{N_{i}} \times 1000000
$$

where:

$P_{i}=$ Publications per million of inhabitants

$P_{S}=$ Number of Publications indexed in SCOPUS

$N_{i}=$ Number of inhabitants

As can be seen, the previous equation will allow a proper classification of the countries by their scientific production indexed in SCOPUS.

\section{Results}

The results obtained after processing and analyzing the collected data were divided into two sections for better understanding. The first section will show a comparative analysis of the scientific production indexed in SCOPUS in the 13 countries of South America. The second section will show the Bolivian 
universities' scientific production indexed in SCOPUS and how they are positioned in Ibero-America and the country.

\subsection{Scientific Production in South America}

It is intended to analyze and compare the entire scientific South American region's scientific production to observe its evolution over the last ten years and, above all, to identify and diagnose the growth of scientific production in Bolivia.

Therefore, to develop a fair comparison, this study proposes comparing South American countries' scientific production per million inhabitants. As mentioned in the methodology section, the scientific production data was consulted on July 27, 2020.

According to the data obtained in the last column of Publications per million inhabitants (Pi), it can be observed that the country in the region with the highest scientific production per million inhabitants is Chile, with a total of 6,597.13 articles per million inhabitants. Secondly is Uruguay, with a total of 4,427.85 articles per million inhabitants. In the third position is Brazil, with 3,567.35 articles per million inhabitants. Then, there is Trinidad and Tobago, with 3,205.99 articles per million inhabitants. Argentina follows it with 3,193.68 articles per million inhabitants.

Subsequently, it is located in Table 1 Colombia, with 2,024.73 articles per million inhabitants. After Colombia, Ecuador can be found with $1,378.45$ articles per million inhabitants. In the eighth position is Peru, with 791.61 articles per million inhabitants. Subsequently, Suriname is found with 776.05 articles per million inhabitants. Venezuela follows with 664.87 articles per million inhabitants. In the eleventh position is Guyana, with 587.93 articles per million inhabitants. Afterward is Paraguay with 343.58 scientific articles per million inhabitants and finally Bolivia with 303.97 articles per million inhabitants.

Figure 1 shows the difference between the total scientific production of the South American countries from 2010 to 2020 (A) and the scientific production per million inhabitants (B) during the same period.

As shown in Fig. 1 A), if only the total number of scientific publications were counted, Brazil would be found in the first place by a significant difference. However, when considering the population factor, it can be observed in Fig 1. B) that Chile rises to first place. Another compelling case to comment on is one of Peru and Ecuador. It can be seen in Table 1 that Peru, until 2015, had higher scientific production than Ecuador. But as can be observed in 2016, Ecuador begins to increase its scientific production and exceeded the Peruvian scientific production. Additionally, it can be observed that Trinidad and Tobago, despite having a reduced scientific production that remains relatively constant throughout the ten years of study. When considering the number of inhabitants to calculate scientific production per million of inhabitants, this country is located in a good position within Table 1. Finally, Venezuela, unlike the rest of the countries in the region that are increasing their scientific production year after year, can be observed that Venezuela is decreasing its scientific production.

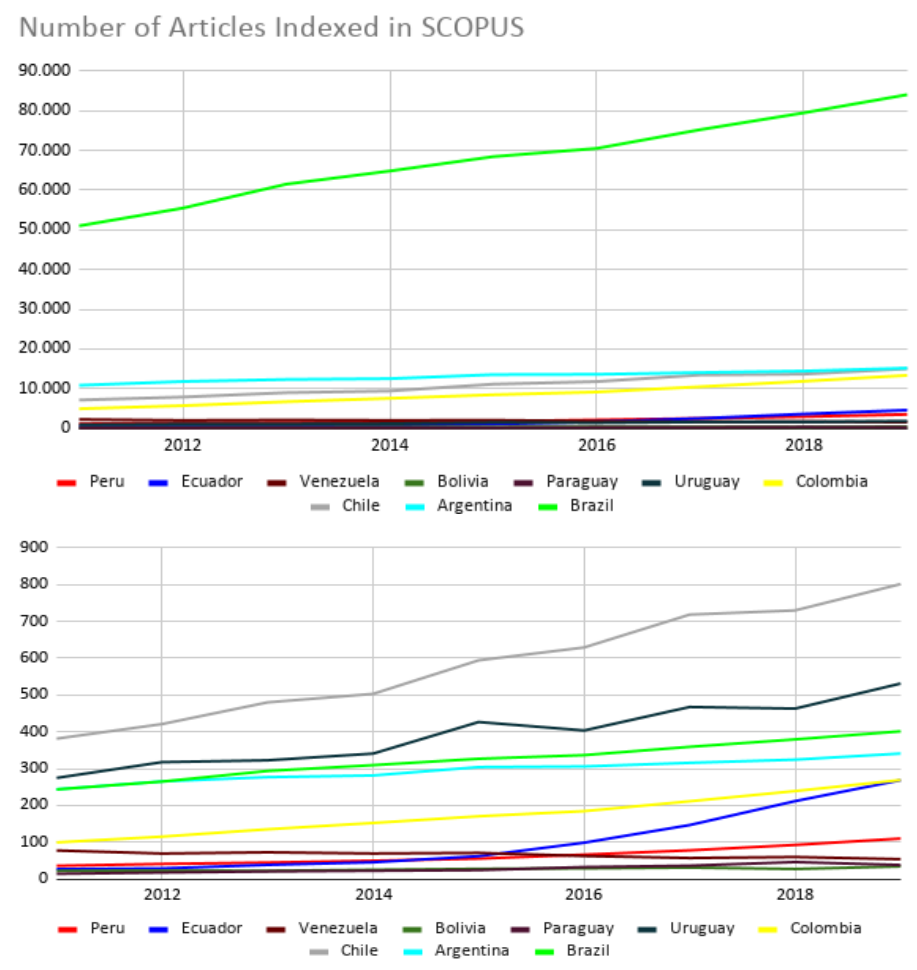

Figure 1: Scientific Production in the South American countries A) Total number of publications from 2010 to 2020 B) Publications per million of inhabitants (Pi)

Table 1: Scientific Production in the South American countries

\begin{tabular}{|c|c|c|c|c|c|c|c|c|c|c|c|c|c|c|}
\hline \multirow[b]{2}{*}{ Country } & \multicolumn{14}{|c|}{ Scientific Production indexed in SCOPUS } \\
\hline & $\begin{array}{l}\text { Number of } \\
\text { inhabitants }\end{array}$ & 2010 & 2011 & 2012 & 2013 & 2014 & 2015 & 2016 & 2017 & 2018 & 2019 & 2020 & TOTAL & $\mathbf{P i}$ \\
\hline Chile & $18,729,200$ & 7,147 & 7,889 & 8,994 & 9,426 & 11,134 & 11,788 & 13,462 & 13,675 & 15,016 & 15,818 & 9,210 & 123,559 & $6,597.13$ \\
\hline Uruguay & $3,449,300$ & 948 & 1,096 & 1,113 & 1,176 & 1,472 & 1,393 & 1,613 & 1,598 & 1,833 & 1,935 & 1,096 & 15,273 & $4,427.85$ \\
\hline Brazil & $209,469,300$ & 51,028 & 55,492 & 61,532 & 64,848 & 68,472 & 70,543 & 75,270 & 79,505 & 84,090 & 86,815 & 49,655 & 747,250 & $3,567.35$ \\
\hline $\begin{array}{l}\text { Trinidad and } \\
\text { Tobago }\end{array}$ & $1,389,900$ & 399 & 441 & 403 & 355 & 493 & 357 & 421 & 448 & 444 & 447 & 248 & 4,456 & $3,205.99$ \\
\hline Argentina & $44,494,500$ & 10,851 & 11,807 & 12,322 & 12,526 & 13,539 & 13,616 & 14,052 & 14,437 & 15,177 & 14,800 & 8,974 & 142,101 & $3,193.68$ \\
\hline Colombia & $49,648,700$ & 4,943 & 5,721 & 6,713 & 7,564 & 8,469 & 9,161 & 10,492 & 11,872 & 13,359 & 14,438 & 7,793 & 100,525 & $2,024.73$ \\
\hline Ecuador & $17,084,400$ & 460 & 492 & 657 & 777 & 1,061 & 1,687 & 2,506 & 3,618 & 4,591 & 4,970 & 2,731 & 23,550 & $1,378.45$ \\
\hline Peru & $31,989,300$ & 1,149 & 1,313 & 1,432 & 1,591 & 1,774 & 2,117 & 2,493 & 2,964 & 3,519 & 4,409 & 2,562 & 25,323 & 791.61 \\
\hline Suriname & 575,991 & 15 & 12 & 27 & 40 & 23 & 40 & 65 & 51 & 67 & 71 & 36 & 447 & 776.05 \\
\hline Venezuela & $28,870,200$ & 2,240 & 2,002 & 2,096 & 2,006 & 2,052 & 1,807 & 1,650 & 1,729 & 1,558 & 1,355 & 700 & 19,195 & 664.87 \\
\hline Guyana & 779,004 & 42 & 25 & 36 & 34 & 33 & 39 & 45 & 40 & 64 & 54 & 46 & 458 & 587.93 \\
\hline Paraguay & $6,956,100$ & 99 & 123 & 144 & 156 & 168 & 226 & 252 & 321 & 265 & 413 & 223 & 2,390 & 343.58 \\
\hline Bolivia & $11,353,100$ & 251 & 262 & 254 & 286 & 314 & 329 & 353 & 310 & 388 & 430 & 274 & 3,451 & 303.97 \\
\hline
\end{tabular}


In Bolivia's case, it can be observed that, although it is in the last position concerning the other countries of the region if the number of inhabitants is taken into account Fig. 1 B). However, it climbs ranks in Table 1, reaching the tenth position if only the total scientific production over ten years is taken into account Fig. $1 \mathrm{~A}$ ), with a total of 3,471 scientific articles indexed in SCOPUS from 2010 to mid-2020.

Besides, from 2010 to 2017, Bolivia shows a growth in scientific production that remained relatively constant over time; Bolivia presents two decreases registered, one in 2012 with a reduction of $3.05 \%$ and another reduction of $12.18 \%$ in 2017 . Also, it can be observed that there has been a growth in scientific production, especially during the last two years, since Bolivia presented an increase of $25.16 \%$ in 2018, which is the highest percentage of growth registered in the previous ten years. It has been possible to observe another increase reported in 2019 of $10.82 \%$.

Finally, it can be seen that by the end of July 2020, Bolivia already presents a total of 274 publications indexed in SCOPUS, which represents $63.72 \%$ of the total scientific production of 2019 . This percentage leads to thinking that this year will present growth in scientific production compared to what was obtained the previous year.

\subsection{Scientific Production in the Bolivian Universities}

As explained in the methodology section, the SIR World and SIR Iber reports were consulted to identify Bolivia's higher education institutions with the necessary scientific production to enter one or both rankings.

Consulting the SIR World 2020 report, it was found that only one Bolivian university is present in the ranking, in the 774th position was the Universidad Mayor de San Andrés (UMSA). This university is an autonomous public university located in La Paz, which is the seat of Bolivia's government. It is essential to mention that it is the first time that a Bolivian university has managed to overcome the fence of 100 publications and enter this ranking. The UMSA in 2018 managed to reach 110 scientific publications indexed in SCOPUS, the reason that allowed it to represent the country in this ranking.

As consulted in SIR World [18], the Universidad Mayor de San Andrés published in 85 scientific journals and different areas of research, as can be seen in Fig. 2:

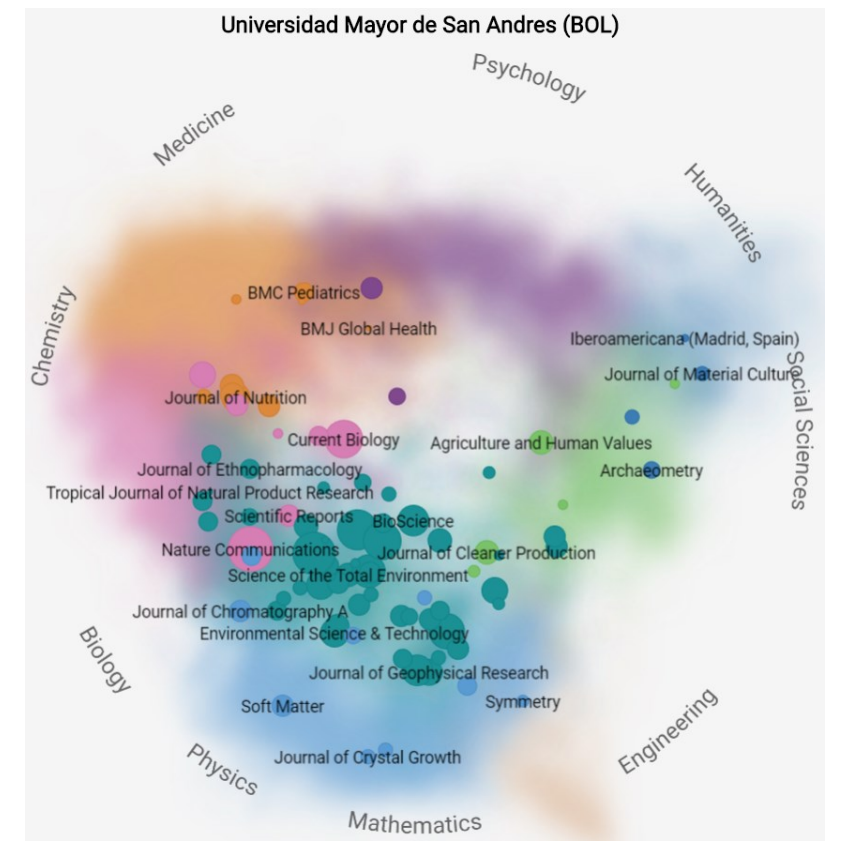

Figure 2: Research topics of the Universidad Mayor de San Andrés (UMSA) [18]

In Fig. 2, each circle's spatial position represents the scientific article's research topic; for its part, the colored spots indicate the research areas. The circles' size represents the value of the SCImago Journal \& Country Rank (SJR) of the publication. It can be seen that there is a predominance of publishing in the areas of biology and medicine.

Furthermore, when consulting the SIR Iber 2020 report, the list of 26 Bolivian universities that accomplished to enter that IberoAmerican ranking was compiled, as can be seen in Table 2:

Table 2: Bolivian universities in SIR Iber 2020

\begin{tabular}{ccccccccc}
\hline IBE & LAC & CO & Organization & Country & O & IC & \%Q1 & \%Lead \\
\hline 343 & 255 & 1 & Universidad Mayor de San Andrés & BOL & 497 & 89.34 & 60.36 & 32.39 \\
463 & 369 & 2 & Universidad Mayor de San Simón & BOL & 214 & 90.65 & 55.61 & 37.85 \\
559 & 462 & 3 & Universidad Autónoma Gabriel Rene Moreno & BOL & 86 & 91.86 & 70.93 & 20.93 \\
559 & 462 & 3 & Universidad Católica Boliviana San Pablo & BOL & 86 & 84.88 & 39.53 & 27.91 \\
607 & 509 & 4 & Universidad San Francisco Xavier de Chuquisaca & BOL & 35 & 94.29 & 48.57 & 17.14 \\
608 & 510 & 5 & Universidad Privada Boliviana & BOL & 34 & 91.18 & 38.24 & 20.59 \\
616 & 518 & 6 & Universidad Autónoma del Beni José Ballivián & BOL & 26 & 92.31 & 73.08 & 19.23 \\
625 & 527 & 7 & Universidad Autónoma Tomas Frías & BOL & 17 & 100 & 64.71 & 0 \\
625 & 527 & 7 & Universidad Técnica de Oruro & BOL & 17 & 88.24 & 23.53 & 17.65 \\
631 & 533 & 8 & Universidad Autónoma Juan Misael Saracho & BOL & 11 & 90.91 & 45.45 & 9.09 \\
631 & 533 & 8 & Universidad Privada de Santa Cruz de la Sierra & BOL & 11 & 81.82 & 63.64 & 18.18 \\
634 & 536 & 9 & Universidad Amazónica de Pando & BOL & 8 & 100 & 62.5 & 0 \\
634 & 536 & 9 & Universidad Andina Simón Bolívar, Bolivia & BOL & 8 & 50 & 12.5 & 62.5 \\
635 & 537 & 10 & Universidad Privada Franz Tamayo & BOL & 7 & 71.43 & 57.14 & 71.43 \\
636 & 538 & 11 & Universidad Pública de El Alto & BOL & 6 & 100 & 33.33 & 0
\end{tabular}




\begin{tabular}{|c|c|c|c|c|c|c|c|c|}
\hline 637 & 539 & 12 & Universidad Privada del Valle & BOL & 5 & 100 & 60 & 20 \\
\hline 638 & 540 & 13 & Universidad de Aquino Bolivia & BOL & 4 & 75 & 0 & 25 \\
\hline 639 & 541 & 14 & Escuela Militar de Ingeniería & BOL & 3 & 100 & 33.33 & 66.67 \\
\hline 639 & 541 & 14 & Universidad Nuestra Señora de La Paz & BOL & 3 & 66.67 & 66.67 & 66.67 \\
\hline 640 & 542 & 15 & Universidad de la Cordillera & BOL & 2 & 100 & 50 & 0 \\
\hline 640 & 542 & 15 & Universidad Nacional Siglo XX & BOL & 2 & 100 & 50 & 0 \\
\hline 640 & 542 & 15 & Universidad Nur & BOL & 2 & 50 & 0 & 50 \\
\hline 640 & 542 & 15 & Universidad San Francisco de Asís & BOL & 2 & 100 & 0 & 0 \\
\hline 641 & 543 & 16 & Universidad de los Andes, Bolivia & BOL & 1 & 0 & 0 & 100 \\
\hline 641 & 543 & 16 & Universidad Privada Abierta Latinoamericana & BOL & 1 & 100 & 0 & 0 \\
\hline 641 & 543 & 16 & Universidad Tecnológica Boliviana & $\mathrm{BOL}$ & 1 & 0 & 0 & 100 \\
\hline
\end{tabular}

Table 2 shows the 26 Bolivian universities present in the SIR Iber 2020 ranking. Also, it can be seen in the respective position of the institution in Ibero-America (IBE) in Latin America (LAC) and in the country itself $(\mathrm{CO})$ according to its scientific production. Besides, in column $(\mathrm{O})$, the institution's total number of publications indexed in SCOPUS can be observed. Also, in the column (IC), the percentage of the institution's international collaboration with other scientific networks can be seen to develop joint research. Likewise, in the column (\% Q1), it can be observed the percentage of scientific publications produced by the institution that are published in journals that are located in the highest quartile of each category of knowledge, according to the SCImago Journal Rank. Finally, in the column (\% Lead), it can be seen the percentage of papers published by the institution whose principal researcher, that is, the corresponding author of the document belongs to that institution.

Also, it can be observed that the university in the first place is the Universidad Mayor de San Andrés, with a total of 497 publications indexed in SCOPUS. Followed by the Universidad Mayor de San Simón with 214 publications and in third place in the country is the Universidad Autónoma Gabriel René Moreno with a total of 86 publications indexed in SCOPUS.

It is essential to mention that most institutions have a high percentage of international collaboration (IC), except for four universities. This factor is favorable for Bolivian scientific production since it is crucial to forming scientific networks to carry out research and inter-institutional publications.

Besides, it can be observed that in the case of the Universidad Autónoma del Beni Jose Ballivián presents a total of 26 publications indexed in SCOPUS, of which $73.08 \%$ are published in journals that are located in the first quartile of the SCImago Journal Rank. This factor is an indicator of its scientific production's institutional capacity to reach a high expected impact level.

Finally, an essential aspect of analyzing is institutional leadership in scientific production. It can be seen that of the five institutions that lead the ranking in the country that the Universidad Mayor de San Simón is the one that presents the highest percentage of leadership with $37.85 \%$. However, it can be observed that it is a low percentage, which means that although the institution is developing publications, the principal author, the corresponding author of the scientific publications, does not belong to the institution. Contrarily, there are universities with less scientific production but with high leadership percentages, such as the Universidad Privada Franz Tamayo.

As consulted in the SIR Iber 2020 report and as summarized in Table 2, it can be indicated that six higher education institutions represent the first five places in the ranking of scientific production in Bolivia. There are six because there is a third-place tie between the Universidad Autónoma Gabriel René Moreno and the Universidad Católica Boliviana San Pablo with 86 publications indexed in SCOPUS.

Consequently, in Table 3, it can be seen the scientific production for 2019 and 2020 of the institutions corresponding to the top five positions in the country:

Table 3: Scientific production of Bolivian universities

\begin{tabular}{lcc}
\cline { 2 - 3 } & \multicolumn{2}{c}{$\begin{array}{c}\text { Scientific Production } \\
\text { indexed in SCOPUS }\end{array}$} \\
\hline University & $\mathbf{2 0 1 9}$ & $\mathbf{2 0 2 0}$ \\
\hline Universidad Mayor de San Andrés & 99 & 84 \\
Universidad Mayor de San Simón & 51 & 27 \\
Universidad Autónoma Gabriel Rene Moreno & 14 & 14 \\
Universidad Católica Boliviana San Pablo & 21 & 11 \\
Universidad San Francisco Xavier de & & 3 \\
Chuquisaca & 10 & 12 \\
Universidad Privada Boliviana & 23 & \\
\hline
\end{tabular}

Source: SCOPUS Database

As previously mentioned, the SIR Iber report is a ranking that takes into account five years to perform its analysis. In this case, the 2020 report was prepared to take into account indicators corresponding to five years from 2014 to 2018. For this reason, Table 3 has been compiled the total number of publications indexed in SCOPUS for the year 2019 and part of 2020 to be able to observe the scientific production developed by the universities located in the top five positions in the country in recent years.

Therefore, in Table 3, it can be observed that the Universidad Mayor de San Andrés has registered for 2019 a total of 99 publications indexed in SCOPUS and for 2020 a total of 84 publications. If this institution keeps working, in the same way, it could reach the 100 scientific publications to be included again in the ranking SIR World.

Moreover, it can be seen that the Universidad de San Simón has a total of 51 and 27 indexed publications for the years 2019 and 2020, respectively. It can also be observed that the Universidad Autónoma Gabriel René Moreno had 14 indexed publications for 
2019 and 14 publications so far in 2020. Subsequently, the Universidad Católica Boliviana San Pablo can be observed. It is essential to mention that this university is the first private university in the top five; this university has a scientific production of 21 indexed publications for 2019 and 11 publications for 2020 . Also, it can be seen that the Universidad San Francisco Xavier de Chuquisaca presents a scientific production of 10 and 3 publications indexed in SCOPUS for 2019 and 2020, respectively. Finally, the second private university in the top 5 is the Universidad Privada Boliviana, with a scientific production of 23 indexed publications for 2019 and 12 indexed publications so far in 2020. If this university maintains the same production rhythm can ascend positions in the next SIR Iber report.

\section{Discussion and Conclusions}

Higher education institutions are called to guarantee the sustainable development goal of quality education, for which, in addition to teaching activities, they must concentrate on research and scientific production.

The scientific production in Bolivia is compared with the production of the other countries of the South American region for ten years from 2010 to the present; it can be seen that the country is among the last positions with a total of 3,451 publications indexed in SCOPUS and 303.97 publications per million inhabitants.

As has been observed, the scientific production indexed in SCOPUS of Bolivia has had a growth of $71.32 \%$ from 2010 to 2019. Still, to know if this growth has been accelerated or slow, it is necessary to compare Bolivia's case with another country's scientific production. For developing this comparison, Peru was chosen, an Andean and neighbor country. Peru presents a growth of $283.72 \%$ from 2010 to 2019 ; it could be said that its scientific production indexed in SCOPUS has almost quadrupled.

To analyze Peru's growth, it is necessary to mention that there have been fundamental changes in two of the three pillars that support research; since there have been changes at the State level and at the university level that strengthen its scientific production. Starting in 2013, the National Council of Science, Technology, and Innovation (CONCYTEC) have provided more funds for two large programs. The first is the development of theoretical and applied research by Peruvian universities, and the second is aimed at the repatriation of Peruvian scientists. Likewise, in 2014 the new university law was approved. With this, it was urged that all Peruvian universities could comply with the necessary quality conditions $(\mathrm{CBC})$ to obtain a license granted by the National Superintendency of Higher University Education (SUNEDU) and continue in operation [19]. This law's critical point is that one of the necessary quality conditions required by SUNEDU is research. This condition has allowed the creation of research lines related to professional careers, increased teachers who carry out research, students with research skills, and a more significant presence of Peruvian universities in international rankings.

The low growth in Bolivia's scientific production could be due to several factors. For example, the Vice Ministry of Science and Technology (VCyT), which belongs to the Ministry of Education, focuses on strengthening science education programs and scientific dissemination. Still, it must expand its scope to the management and distribution of competitive funds for research. Furthermore, most university teachers, especially in private universities, do not work full-time. Additionally, teachers are overloaded with teaching hours and administrative work $[2,5,10]$. Besides, there is a lack of a repatriation program for Bolivian scientists specialized abroad, causing the loss of Bolivian talents. The impact of these factors is evidenced in the low quantity of fulltime equivalent researchers in the country, which, according to UNESCO, are 2,218 full-time equivalent researchers for the year 2020 [7]. Finally, it can also be mentioned scarce funds to finance research projects and centralization of research infrastructure, since 183 research and development centers are located mainly in three Bolivia departments: La Paz, Cochabamba, and Santa Cruz [5].

However, the Bolivian government has identified some aspects that it must strengthen to increase its scientific production. In that sense, in 2016, it organized the First Meeting of Bolivian Scientists Living Abroad for Scientific and Technological Liberation [20], in which 54 researchers based in different parts of the world have participated together with representatives from ministries and private companies. This meeting had the objective of exchanging proposals and ideas to identify actions and mechanisms to strengthen science, technology, and innovation in Bolivia in the short, medium, and long term. It is essential to follow up and begin to implement the suggested strategic mechanisms.

Besides, it could be seen that of a total of 59 universities that constitute the university higher education system in Bolivia, only one institution could enter the SIR World report for the year 2020, ranking in the position 774th. Also, 26 universities are present in the SIR Iber 2020 report, which means that only $44.07 \%$ of the country's existing higher education institutions entered this ranking. They produced a total of 1,010 publications indexed in SCOPUS for the period analyzed. These scientific publications from higher education institutions represent $61 \%$ of the national total.

Besides, it was possible to observe that of all the institutions present in the SIR Iber ranking, 11 were autonomous public universities, 12 were private universities, and 3 were private universities attached to CEUB. This situation shows that $100 \%$ of autonomous public universities and private universities attached to CEUB managed to enter the SIR Iber 2020 report. Only $30.77 \%$ of Bolivian private universities managed to enter the ranking. Moreover, it has been possible to establish, as can be seen in Fig.3, that autonomous public universities have developed $84.36 \%$ of scientific production. In comparison, private universities attached to the CEUB have produced $8.92 \%$ of publications. Private universities have generated only $6.72 \%$ of the scientific production reported in the five years analyzed, which shows that 27 of the 39 private universities in Bolivia are not prioritizing research. This situation is evidence that, for the moment, private universities are not taking advantage of the existing relationship that some of these institutions have in a more significant way with the business production system of Bolivia. This factor is essential since a synergy could be generated; it would create spaces for research, innovation, and learning for both companies and universities.

It is essential to mention that at the time of compiling Bolivian universities' scientific production data in the SCOPUS database, it was possible to reveal that $89.83 \%$ of the country's universities 
have not created their institutional profile. This factor is challenging to verify each institution's number of publications; in this sense, it is recommended that all higher education institutions in the country create their institutional profile in SCOPUS.

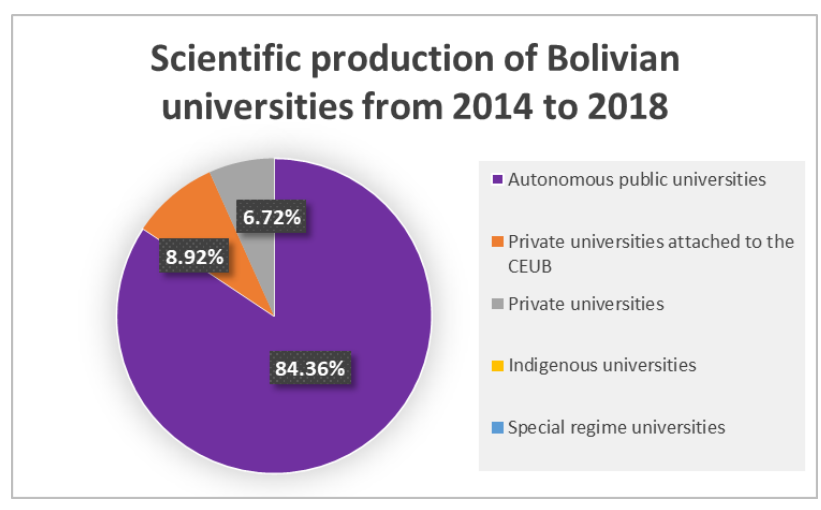

Figure 3: Scientific production of Bolivian universities from 2014 to 2018

Finally, analyzing the scientific production indexed in SCOPUS of 2019 and 2020, it can be observed that the Universidad Mayor de San Andrés is emerging to overcome the fence of 100 publications once again and represent Bolivia in the SIR Wolrd ranking.

We believe that Bolivia should begin to propose changes in a country's research tripod's policies and mechanisms, including the Bolivian state, universities, and industry, to strengthen scientific and research activities. It is also crucial to enhance the Vice Ministry of Science and Technology activities, which should begin by identifying national strategic priorities and calling on universities and other entities to develop research in those defined lines to achieve sustainable development.

It is crucial that in the future, the country can define national policies to promote scientific activities in higher education institutions, both in public universities and private universities.

Moreover, it is essential to start considering the implementation of programs for the repatriation of scientists to avoid the brain drain, which is a phenomenon that is currently observed in Bolivia. It is also necessary to strengthen existing postgraduate programs and create new ones, as this will allow increasing the research-trained resources in the country.

Finally, other countries' steps in the region can be analyzed and followed. For example, Ecuador and Peru's case, whose firsts steps were to define priority research lines in the country and develop calls for competitive funds to finance research projects following those research lines.

\section{Conflict of Interest}

The authors declare no conflict of interest.

\section{References}

[1] UNESCO, Education for Sustainable Development Goals: Learning Objectives, UNESCO, 2017. ISBN 978-92-3-100209-0

[2] L. I. Litzner Ordóñez, W. Rieß, "La Educación para el Desarrollo Sostenible en la universidad boliviana. Percepciones del profesorado". Teoría de la Educación. Revista Interuniversitaria, 31, 149-173, 2019, DOI: http://dx.doi.org/10.14201/teri.19037.

[3] C. Weise, La construcción de políticas públicas universitarias en el período neoliberal: estado y universidad, contradicciones en una década de desconcierto: el caso de Bolivia, Master's Thesis, FLACSO, Argentina. 2005. http://hdl.handle.net/10469/1057.

[4] C. Weise, J. L. Laguna, "La educación superior en la región andina: Bolivia, Perú y Ecuador" Revista da Avaliação da Educação Superior (Campinas), 13(2), 425-450, 2008, https://doi.org/10.1590/S1414-40772008000200009.

[5] G. Rodríguez Ostria, C. Weise Vargas, Educación Superior Universitaria en Bolivia -Estudio Nacional, Cochabamba: Iesalc-Unesco-Editorial Talleres Gráficos «Kipus», 2006.

[6] World Bank Data Team (2018). World population 2018. World Bank open access data catalog. Available in: http://databank.worldbank.org/data/download/POP.xls [30 July 2020]

[7] UNESCO (2020). Global Investments in R\&D. Fact Sheet No. 59. FS/2020/SCI/59. Consulted: [21 August 2020]. Available in: http://uis.unesco.org/sites/default/files/documents/fs59-global-investmentsrd-2020-en.pdf

[8] Viceministerio de Educación Superior de Formación Profesional Ministerio de educación de Bolivia (2016). Guía de Universidades del Estado Plurinacional de Bolivia. Available in: https://www.minedu.gob.bo/files/publicaciones/vesfp/dgesu/GUIAUNIVERSIDADES-2016.pdf [29 July 2020]

[9] G. R. Ostria, "Debates y desafíos: Reformas de la educación superior en Bolivia, una sociedad multicultural" Policy Futures in Education, 7(5), 513531, 2009, https://doi.org/10.2304/pfie.2009.7.5.513.

[10] A. Martínez Barrientos, S. Santillán Butrón, M. Loayza Melgarejo (2016). Educación Superior en Iberoamérica. Informe Nacional: Bolivia.

[11] UNIVERSIA (2016). Educación superior en Iberoamérica. Informe nacional: Bolivia [Online]. Consulted: [14, July, 2020] Available in: https://cinda.cl/wp-content/uploads/2019/01/educacion-superior-eniberoamerica-informe-2016-informe-nacional-bolivia.pdf

[12] S. E. Miguel, "Revistas y producción científica de América Latina y el Caribe: su visibilidad en SciELO, RedALyC y SCOPUS" Revista Interamericana de Bibliotecología, 34 (2), 187-199, 2011, ISSN: 0120-0976.

[13] Scimago Institutions Rankings (2020). Ranking Methodology. [Online]. Consulted: [21 July 2020]. Available in: https://www.scimagoir.com/methodology.php

[14] F. De-Moya-Anegón, E. Herrán-Páez, A. Bustos-González, E. CoreraÁlvarez, G. Tibaná-Herrera, F. Rivadeneyra. Ranking iberoamericano de instituciones de educación superior 2020 (SIR Iber). Granada: Ediciones Profesionales de la Información, 2020. ISBN: $978 \quad 84 \quad 12023930$ https://doi.org/10.3145/sir-iber-2020

[15] Academic Ranking of World Universities (2019). ARWU 2019 Methodology. [Online]. Consulted: [26 July 2020]. Available in: http://www.shanghairanking.com/ARWU-Methodology-2019.html

[16] Elsevier (2020). All solutions: SCOPUS. [Online]. Consulted: [06 August 2020]. Available in: https://www.elsevier.com/solutions/scopus

[17] Elsevier (2020). Elsevier history. [Online]. Consulted: [10 August 2020]. Available in: https://www.elsevier.com/about/history

[18] Scimago Institution Rankings (2020). Institution Universidad Mayor de San Andres. [Online]. Consulted: [14 August 2020]. Available in: https://www.scimagoir.com/institution.php?idp=609

[19] Superintendencia Nacional de Educación Superior Universitaria. (2015). Modelo de licenciamiento institucional y su implementación en el sistema universitario peruano.

[20] E. A. G. Rocha, M. G. G. Alvestegui, A. S. G. Amaya, U. F. M. Covarrubias, S. A. Q. Condoretty, L. L. Torres, M. M. SupAgro, "Encuentro de Científicos Bolivianos Radicados en el Exterior, para la Liberación Científica y Tecnológica: Comentarios Breves", (2016). 